\title{
PERAN CUSTOMER INVOLVEMENT DAN CORPORATE IMAGE DALAM HUBUNGAN E-WOM DENGAN PURCHASE INTENTION
}

\author{
Fatik Rahayu \\ Fakultas Ekonomi dan Bisnis, Universitas Trisakti
}

\begin{abstract}
There are many studies about the impact of e-WOM on purchase intention. Rarely studies that focus on the role of customer involvement and corporate image in the relationship between e-WOM with purchase intension especially in education context. The purposes of this study are to investigate the moderating effect of customer involvement and mediating effect of corporate image in the relationsip between e-WOM with purchase intention in higher education. The sample are students of senior high school who have ever search for opinions or reviews through the internet before choosing the university. A SEM is used to asses the relationship of the researh model. The results show that customer involvement has moderating effect and corporate image has mediating effectc in relationship between e-WOM with purchase intention. These results provide new insight into the relationship model between e-WOM with purchase intention in higher education context.
\end{abstract}

Keywords : e-WOM, Purchase Intention, Customer Involvement, Corporate Image, Higher Education, Moderating Effect, Mediating Effect 


\section{Fatik Rahayu}

\section{Pendahuluan}

Perkembangan teknologi informasi dan komunikasi sekarang ini telah mengubah cara orang berkomunikasi, termasuk membantu konsumen bertukar informasi tentang produk secara online. Konsumen dapat menuliskan opini, komentar bahkan review mereka tentang suatu produk melalui forum diskusi, review website, e-bulletin board system, newsgroup atau bahkan melalui jejaring sosial seperti facebook, twitter, youtube dan instagram (Cheung and Thadani, 2010).Komunikasi tentang sebuah produk antar konsumen secara online ini disebut electronic word-of-mouth (e-WOM). Melalui komunikasi e-WOM, opini konsumen dapat tersebar lebih cepat dan luas. E-WOM memudahkan konsumen dalam mendapatkan berbagai informasi atau rekomendasi sebelum memutuskan untuk membeli sebuah produk. Hal tersebut mempengaruhi para pelaku pemasaran dalam menyusun strategi dan melakukan pendekatannya terhadap pasar. Teknologi internet sebagai media pertukaran secara elektronik memberikan kesempatan baru untuk menjadikan internet sebagai salah satu alat pemasaran yang efektif, baik bagi organisasi bisnis maupun non bisnis termasuk lembaga pendidikan.

Dalam penelitian ini, e-WOM dilihat melalui tiga dimensi (Bataineh, 2015). Pertama kredibilitas e-WOM (e-WOM credibility). Kredibilitas informasi biasanya berhubungan dengan kapasitas penulis atau lembaganya. Kedua, kualitas e-WOM (e-WOM quality), merupakan tingkat sejauh mana kejelasan ulasan dan alasan yang masuk akal. Dan ketiga yaitu kuantitas e-WOM (e-WOM quantity), berkaitan dengan banyaknya jumlah perbincangan yang dianggap berhubungan dengan tingkat ketenaran suatu merek dan dapat mengurangi resiko pembelian.

Perceived e-WOM akan mempengaruhi corporate image (Bataineh, 2015). Kesan atau image yang baik terhadap perusahaan, produk atau jasa, akan menjadi kunci untuk meningkatkan niat pembelian konsumen. Minat atau niat beli konsumen merupakan hal yang penting bagi perusahaan karena niat merupakan salah satu faktor utama yang mempengaruhi seseorang akan melakukan suatu tindakan. Dengan kata lain corporate image merupakan salah satu faktor yang mempengaruhi purchase intention. Hasil penelitian Lin et al. (2013) menunjukkan bahwa pengaruh e-WOM terhadap purchase intention ditentukan juga oleh customer involvement. Semakin tinggi keterlibatan konsumen maka semakin kuat pengaruh e-WOM terhadap purchase intention.

Beberapa penelitian mengenai pengaruh perceived e-WOM terhadap purchase intention telah banyak dilakukan, tetapi belum banyak penelitian yang mengikutsertakan perancorporate image sekaligus peran customer involvement sebagai variabel yang memediasi dan memoderasi hubungan perceived e-WOM terhadap purchase intention. 
Penelitian mengenai pengaruh perceived e-WOM ini juga masih jarang dilakukan di dunia pendidikan. Penelitian ini menguji peran corporate image dan peran customer involvement sebagai variabel yang memediasi dan memoderasi hubungan perceived e-WOM terhadap purchase intention dalam konteks jasa pendidikan tinggi di Indonesia.

Berdasarkan uraian latar belakang, maka perumusan masalah dalam penelitian ini diindentifikasi sebagai berikut:

1. Apakah perceived e-WOM memiliki pengaruh terhadap purchase intention?

2. Apakahperceived e-WOM memiliki pengaruh terhadap corporate image?

3. Apakah corporate image memiliki pengaruh terhadap purchase intention?

4. Apakah pengaruh perceived e-WOM terhadap purchase intention dimediasi oleh corporate image?

5. Apakah pengaruh perceived e-WOM terhadap purchase intention dimoderasi oleh customer involvement?

\section{Kerangka Teoritis dan Pengembangan Hipotesis}

Electronic Word-Of-Mouth (e-WOM)

Secara umum word of mouth atau sering disingkat WOM adalah salah satu alat komunikasi pemasaran yang tergabung dalam promotion mix. Komunikasi pemasaran merupakan komunikasi yang bertujuan untuk membangun kesadaran, meningkatkan minat dan ketertarikan konsumen terhadap suatu produk ataupun merek yang pada akhirnya akan membuat konsumen melakukan tindakan pembelian terhadap merek tersebut (Kotler and Keller, 2012). Dalam menyusun komunikasi pemasaran, pemasar harus mengidentifikasi siapa yang akan menjadi receiver. Dengan mempelajari karakteristik receiver, pemasar dapat menyesuaikan tujuan komunikasi, alat dan media komunikasi yang tepat, sumber penyampai pesan yang lebih dipercaya maupun daya tarik pesan yang akan dipilih. Komunikasi pemasaran ada yang bersifat massal dan ada yang bersifat personal.

Traditional word of mouth yang merupakan komunikasi lisan antar konsumen telah terbukti mempunyai peran besar pada keputusan pembelian konsumen. Word of mouth seringkali dikatakan dengan istilah viral marketing, yaitu sebuah teknik pemasaran yang digunakan untuk menyebarkan sebuah pesan pemasaran dari satu pengguna kepada pengguna lain, yang dapat terus berkembang pesat layaknya sebuah virus.

Word of mouth (WOM) begitu efektif karena memiliki tingkat kepercayaan yang lebih tinggi dibanding alat promosi yang lain. Hal ini disebabkan asal kepercayaanya adalah datang 


\section{Fatik Rahayu}

dari orang yang tidak mendapatkan keuntungan dari rekomendasi mereka. Bagi pengirim, pesan yang diberikan tidak memiliki maksud komersil yang kuat. WOM merupakan tipe komunikasi interpersonal yang mempengaruhi keputusan pemasaran (Hennig Thurau et al., 2004).

Dengan adanya internet terciptalah sebuah paradigma baru dalam komunikasi word of mouth dan inilah awal munculnya istilah electronic Word-of-Mouth atau e-WOM. Menurut Hennig-Thurau, et al. (2004), e-WOM didefinisikan sebagai pernyataan positif dan negatif yang didapat dari konsumen aktual maupun konsumen potensial yang telah memiliki pengetahuan atau pengalaman tentang suatu produk pada sebuah media elektronik. Informasi dari e-WOM biasanya disediakan untuk banyak orang melalui internet. HarrisonWalker (2001) mendefinisikan e-WOM sebagai komunikasi informal dari orang ke orang dimana yang menjadi komunikator adalah orang (non-komersial) yang telah merasakan kinerja dari sebuah merek, produk, organisasi, atau layanan.

Electronic word-of-mouth (e-WOM) berbeda dengan traditional word-of-mouth. Menurut Cheung and Lee (2012), perbedaan tersebut antara lain adalah, pertama, tidak seperti traditional WOM, e-WOM terjadi dengan menggunakan teknologi elektronik seperti forum diskusi online, blog, electronic bulletin board, dan social media lainnya. Kedua, e-WOM lebih mudah diakses daripada traditional WOM, dimana sebagian besar informasi berbasis teks di internet dapat diarsipkan yang di kemudian hari dapat diakses kembali. Ketiga, e-WOM lebih mudah diukur daripada traditional WOM.

Pesan dalam sebuah e-WOM akan menjadi sangat penting sebagai referensi dalam memudahkan konsumen untuk melakukan keputusan pembelian. Pesan e-WOM menjadi sarana penting bagi konsumen untuk mendapatkan informasi tentang kualitas produk dan kualitas pelayanan (Chevalier and Mayzlin, 2006). Selain itu, pesan seperti itu efektif dalam mengurangi resiko dan ketidakpastian yang dialami konsumen saat membeli produk atau jasa, sehingga dapat mempengaruhi minat pembelian dan keputusan pembelian konsumen (Chattereje, 2001). e-WOM mungkin kurang bersifat pribadi karena tidak bertatap muka secara langsung, akan tetapi e-WOM lebih kuat karena informasi diperoleh langsung, memiliki jangkauan yang luas, lebih kredibel karena memiliki bukti, dan dapat diakses oleh banyak orang (Hennig-Thurau, et al., 2004). Lebih lanjut Hennig-Thurau, et al. (2004) menjelaskan bahwa e-WOM merupakan aspek penting dari sebuah ekspresi kepuasan konsumen terhadap suatu brand dan mungkin memiliki dampak pada brand image dan brand awareness. e-WOM juga akan menjadi lebih penting di masa depan sebagai aplikasi jejaring sosial yang menyebar luas. 
Banyak faktor yang dapat mendorong terjadinya e-WOM. Menurut Cheung and Lee (2012), faktor yang paling signifikan dalam mendorong terjadinya e-WOM adalah rasa memiliki sebuah brand, reputasi, dan kebersediaan untuk membantu. Penelitan dari Henning- Thurau, et al. (2004) menemukan faktor pendorong timbulnya e-WOM, yaitu: platform assistance, venting negative feeling, concern for other consumer, extraversion/ positive self enhancement, social benefit, economic incentives, helping the company, advice seeking.

\section{Purchase Intension}

Purchase Intention dapat didefinisikan sebagai niat seorang konsumen untuk membeli sebuah produk (Bian dan Moutinho, 2011). Sedangkan Assael (2001) berpendapat, purchase intention atau niat pembelian merupakan suatu kecenderungan dari seorang konsumen untuk membeli dan mengambil tindakan yang berhubungan dengan pembelian yang muncul sebagai respon terhadap penilaian sebuah obyek. Selain itu, Assael juga menambahkan bahwa minat beli adalah tahap akhir dari suatu proses keputusan pembelian yang kompleks. Mirip dengan pendapat tersebut diatas, pengertian niat pembelian konsumen menurut Kotler and Keller (2012) adalah respon yang timbul pada diri seorang konsumen setelah menerima rangsangan dari produk yang dilihatnya. Rangsangan tersebut akan menimbulkan ketertarikan untuk mencoba produk sampai pada akhirnya timbul keinginan untuk membeli.

Purchase intention memiliki perbedaan dengan behavioral intention. Sebagaimana yang dikemukakan Zeithaml et al.(2012), pada behavioral intention terdapat keinginan untuk menceritakan pengalaman membeli (word of mouth) dan merekomendasikannya kepada orang lain. Sedangkan pada purchase intention hanya berkaitan dengan masalah niat atau keinginan untuk membeli saja (Kim and Hyun, 2011; Di and Wang, 2012).Menurut Zeithaml et al.(2012) keinginan untuk membeli dapat timbul jika barang atau jasa yang ditawarkan sesuai dengan kriteria konsumen.

\section{Corporate Image}

Berbagai definisi mengenai corporate image dapat ditemukan dalam literatur bisnis maupun psikologi. Studi literatur yang dilakukan oleh Bataineh (2015), menemukan bahwa corporate image bisa diartikan sebagai 'identitas' atau 'reputasi'. Dalam arti yang lebih sempit corporate image diangap sebagai persepsi internal tentang identitas perusahaan yang diyakini oleh karyawan. Sedang dalam arti yang luas, corporate image merupakan pandangan mengenai reputasi perusahaan menurut para pemegang saham eksternal, khususnya oleh para pelanggan. Menurut Gronroos (dalam Bataineh, 2015) corporate 


\section{Fatik Rahayu}

image perusahaan dapat dibangun melalui kualitas teknikal (hasil akhir yang diperoleh pelanggan) dan kualitas fungsional (berkaitan dengan cara bagaimana layanan jasa diberikan kepada pelanggan).

Menurut business dictionary, corporate image adalah gambaran mental yang timbul pada penyebutan suatu nama perusahaan. Gambaran mental yang merupakan kesan psikologis ini dapat terus berubah seiring dengan perubahan keadaan perusahaan, liputan media, kinerja perusahaan, atau hal lainnya yang dapat mengubah persepsi masyarakat terhadap perusahaan. Jefkins (2004) menyebutkan image terbagi menjadi lima jenis yaitu:

1. Mirror image, yaitu kesan masyarakat yang muncul saat menilai karyawan perusahaan atau anggota organisasi. Kesan ini biasanya kurang tepat karena kurangnya informasi yang memadai.

2. Current image, yaitu kesan yang didasarkan oleh pemahaman dan pengalaman yang sudah dirasakan masyarakat eksternal.

3. Wish image, yaitu kesan yang diinginkan oleh perusahaan.

4. Multiple image, yaitu kesan yang dapat timbul karena perwakilan perusahaan, seperti kantor cabang, yang membentuk citra tertentu yang belum tentu sesuai dengan kesan perusahaan.

5. Corporate image, citra yang dipandang secara keseluruhan, bukan hanya sekedar pandangan mengenai suatu produk atau pelayanan yang dihasilkan, tetapi juga persepsi terhadap perilaku karyawan maupun prestasi dan kegiatan-kegiatan yang dilakukan organisasi secara umum. Termasuk disini kegiatan pemasaran, kegiatan sosial dan kegiatan bisnis lainnya.

Menurut Norman and Smith (1995) corporate image dapat dipengaruhi oleh beberapa faktor diantaranya adalah advertising, physical image, pengalaman konsumen dalam menggunakan barang atau jasa dan word of mouth. Corporate image dianggap memiliki peran dalam mempengaruhi keputusan pembelian konsumen, terutama apabila persaingan jasa dianggap hampir identik pada kinerja, harga, dan bentuk ketersediaannya (Andreassen and Lanseng, 1998). Oleh karena itu, corporate image membantu perusahaan dalam menciptakan keunggulan kompetitif tersendiri dibandingkan dengan pesaing lainnya (Boyd et al., 2010). Corporate image ada yang positif dan ada yang negatif. Corporate image negatif yang timbul akan mengurangi loyalitas pelanggan dan membuat pelanggan meninggalkan perusahaan atau tidak lagi menggunakan produk atau jasa yang dihasilkan perusahaan, sedangkan corporate image positif dapat menumbuhkan loyalitas pelanggan dan membuat pelanggan tetap menggunakan produk atau jasa yang dihasilkan (Ruben dan Steward, 1998). Menurut Hu et al. (2007), corporate image terdiri dari dua komponen penting yaitu pertama adalah fungsional yang merupakan karakteristik nyata yang dapat 
diukur dan mudah untuk di evaluasi, dan yang kedua adalah komponen emosional seperti perasaan, sikap dan keyakinan seseorang terhadap suatu perusahaan atau organisasi. Komponen emosional ini akan muncul apabila konsumen sudah pernah memiliki pengalaman dengan perusahaan atau organisasi tersebut.

\section{Customer Involvement}

Menurut Peter and Olson (2008), customer involvement adalah persepsi konsumen tentang pentingnya atau relevansi personal suatu objek, kejadian atau aktivitas. Konsumen yang melihat bahwa produk memiliki konsekuensi relevan secara pribadi dikatakan terlibat dengan produk tersebut. Menurut Kotler dan Keller (2012), keterlibatan konsumen berkaitan dengan ketertarikan konsumen mengenai sesuatu obyek tertentu. Dengan semakin meningkatnya keterlibatan, konsumen memiliki motivasi yang lebih besar untuk memperhatikan, memahami, dan mengelaborasi informasi tentang suatu produk.

Hasil studi literatur menunjukkan bahwa dengan adanya customer involvement dapat menciptakan interaksi positif dan kedekatan antara konsumen dengan karyawan yang selanjutnya dapat meningkatkan efektivitas karyawan di dalam menyampaikan produk atau jasa ketika bekerja di dalam perusahaan dan akan menciptakan pengalaman positif konsumen (Fatima dan Razzaque, 2014; Hsu dan Chen, 2008).

Hasil studi literatur menunjukkan bahwa faktor-faktor yang menentukan customer involvement adalah kolaborasi dan kerjasama antara konsumen dengan perusahaan, strategi pemasaran, pengalaman penggunaan produk atau jasa, dan promosi yang dilakukan oleh perusahaan, ketertarikan konsumen terhadap produk atau jasa yang dijual oleh perusahaan, kondisi psikologis, kondisi emosional yang dimiliki oleh konsumen selama proses penyampaian layanan jasa yang dilakukan oleh perusahaan kepada konsumen, interaksi dan kedekatan konsumen dengan perusahaan (Fatima dan Razzaque, 2014; Hsu dan Chen, 2008). Selain faktor tersebut diatas, jenis produk dibawah ini juga menentukan customer involvement (Mowen and Minor, 2002) :

a. self-expresive importance, produk-produk yang membantu orang untuk mengekspresikan konsep diri mereka kepada orang lain.

b. hedonic importance, produk-produk yang dapat menyenangkan, menarik, menggembirakan, mempesona, dan menggairahkan.

c. practical relevance, produk-produk yang mendasar atau bermanfaat untuk alasan yang berfaedah. 
d. purchase risk, produk-produk yang mempunyai resiko ketidakpastian karena pilihan yang buruk akan menjadi sangat merugikan pembeli.

Menurut Fatima dan Razzaque (2013) customer involvement dapat menciptakan perilaku positif terhadap produk atau jasa yang dijual oleh perusahaan dan keinginan konsumen untuk menjalin hubungan dalam jangka panjang dengan perusahaan.

\section{Model Penelitian}

Hasil studi literatur menunjukkan bahwa e-WOM mempunyai pengaruh pada purchase intention (Bataineh, 2015; Lin et al., 2013; Jalilvand and Samiei, 2012; Cheung and Thadani, 2010). e-WOM Credibility mengacu pada sejauh mana informasi dari suatu perbincangan elektronik akan diterima berdasarkan sumber-sumber penyampai yang dapat dipercaya (Fogg et al., 2002). Semakin seorang konsumen merasa bahwa informasi yang didapatkan kredibel, maka akan semakin besar kemungkinan informasi itu dapat membentuk niat beli (Bataineh, 2015). Kualitas e-WOM mengacu pada kekuatan suatu perbincangan elektronik untuk meyakinkan pembacanya yang bersumber dari informasi pesan yang jelas dan lengkap(Bhattacherjee, 2006). Bentuk informasi yang lengkap dan jelas dari sebuah perbincangan elektronik dapat mempengaruhi niat beli (Bataineh, 2015). Selain itu, sebelum menentukan keputusan pembelian, seorang konsumen akan mengumpulkan referensi yang banyak terlebih dahulu untuk mengurangi resiko (Kotler and Keller, 2012). Oleh karena itu, semakin banyak ulasan akan semakin meningkat minat beli seorang konsumen. Hal ini disebabkan jumlah atau kuantitas ulasan menjadi tanda kepopuleran produk atau reputasi merek yang dapat mengurangi perceived risk (Lee et al., 2008; Sher and Lee, 2009).

Namun demikian untuk sampai pada niat pembelian, konsumen perlu diyakinkan tentang corporate image dari sebuah perusahaan atau merk. Membangun kesan yang baik dapat dilakukan melalui proses komunikasi yang efektif. Komunikasi efektif salah satunya dapat dirancang dengan memperhatikan kredibilitas sumber penyampai, kualitas isi dan jumlah pesan yang memadai (Kotler and Keller, 2012). Selain itu, pengaruh e- WOM terhadap purchase intention juga ditentukan oleh tinggi rendahnya customer involvement. Hasil studi literatur juga menunjukkan bahwa besarnya pengaruh e-Wom terhadap purchase intention juga tergantung tinggi rendahnya customer involvement(Lin et al., 2013). Berdasarkan landasan teori tersebut, model penelitian adalah sebagai berikut : 


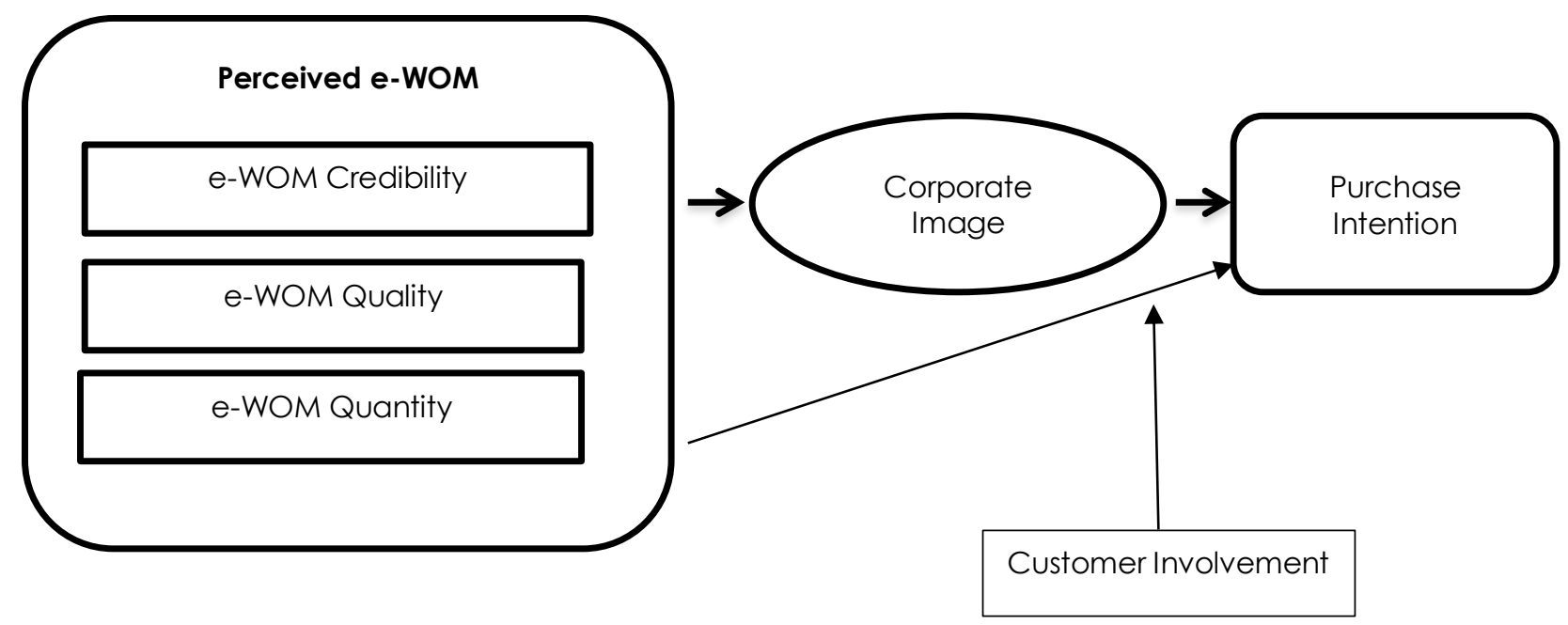

Gambarl Konsekuensi dari Perceived e-WOM

Sumber : Bataineh, 2015; Lin et al., 2013

\section{Pengembangan Hipotesis}

Jika para konsumen memperoleh informasi dari ulasan atau komentar tentang suatu produk dari sumber yang layak dipercaya, informasi cukup jelas disertai alasan kuat dan jumlah informasi juga banyak maka dapat meningkatkan minat untuk mengambil keputusan pembelian terhadap produk atau jasa yang diulas tersebut. Demikian juga dengan para calon mahasiswa, jika ulasan-ulasan yang mereka baca tentang suatu universitas berkualitas, dapat dipercaya dan cukup banyak jumlahnya maka minat mereka untuk mendaftar ke universitas tersebut juga tinggi. Hasil studi literatur menunjukkan bahwa eWOM mempunyai pengaruh pada purchase intention (Bataineh, 2015; Lin et al., 2013; Jalilvand and Samiei, 2012; Cheung and Thadani, 2010).

\section{H1: Terdapat pengaruh perceived e-WOM terhadap purchase intention}

Ketika konsumen akan membuat keputusan pembelian sebuah jasa, maka untuk mengurangi resiko kekecewaan di kemudian hari, mereka akan mencari informasi tentang jasa yang akan dibeli tersebut (Kotler and Keller, 2012; Zeithaml et al., 2012). Jika para konsumen menerima informasi tentang suatu jasa dari sumber yang layak dipercaya, informasi cukup jelas disertai alasan kuat dan jumlah informasi juga banyak maka akan dapat meningkatkan kesan positif terhadap universitas tersebut. Bagi calon mahasiswa, sumber ulasan yang dapat dipercaya, dengan isi yang berkualitas dan jumlah yang 


\section{Fatik Rahayu}

memadai tentang sebuah perguruan tinggi mencerminkan bagaimana kesan atau image dari sebuah universitas tersebut. Hasil studi literatur menunjukkan bahwa e- WOM mempunyai pengaruh pada corporate image (Bataineh, 2015; Jalilvand and Samiei, 2012).

H2: Terdapat pengaruh perceived e-WOM terhadap corporate image

Secara umum, konsumen ingin mendapatkan barang dan jasa dari sebuah perusahaan dengan corporate image yang baik untuk mengurangi berbagai resiko. Dalam penelitian ini, corporate image diukur lewa tindikator seperti tingkat popularitas sebuah universitas, atraktif dalam tampilan fisik (gedung, sarana prasarana), menjadi favorite dan mutu yang dapat dipercaya (memperoleh akreditasi A atau B). Dengan demikian, diharapkan corporate image mempunyai pengaruh terhadap Purchase Intention.Semakin baik corporate image sebuah universitas maka akan semakin tinggi juga minat calon mahasiswa untuk mendaftar ke universitas tersebut. Hasil studi literatur menunjukkan bahwa e-WOM mempunyai pengaruh pada purchase intention (Bataineh, 2015; Jalilvand and Samiei, 2012; Cheung and Thadani, 2010).

H3: Terdapat pengaruh Corporate Image terhadap Purchase Intention.

Jika para konsumen menerima komentar produk dan jasa dari sumber yang layak dipercaya, informasi cukup jelas disertai alasan kuat dan jumlah informasi juga banyak maka akan dapat meningkatkan corporate image suatu universitas yang selanjutnya dapat meningkatkan minat untuk mengambil keputusan mendaftar pada universitas yang diulas tersebut.

H4: Terdapat pengaruhv Perceived e-WOM terhadap Purchase Intention melalui Corporate Image

Pengaruh kredibilitas, kualitas dan kuantitas e-WOM terhadap purchase intention akan ditentukan oleh seberapa tinggi tingkat keterlibatan konsumen (customer involvement). Semakin calon mahasiswa menganggap bahwa pendidikan tinggi merupakan produk yang penting dan berharga bagi kehidupan mereka, maka pengaruh e-WOM terhadap minat mendaftar pada universitas tersebut juga akan semakin tinggi. Hasil studi literatur menunjukkan bahwa pengaruh e-WOM pada purchase intention dimoderasi oleh customer involvement (Lin et al., 2013).

H5: Terdapat pengaruh Perceived e-WOM terhadap Purchase Intention yang dimoderasi oleh customer involvement. 


\section{Metode Penelitian}

Metode Seleksi dan Pengumpulan Data

Metode penarikan sampel yang digunakan adalah metode non - probability sampling. Teknik penarikan sampel dilakukan dengan menggunakan teknik purposive / judgemental sampling yaitu penarikan sampel berdasarkan kriteria - kriteria tertentu. Kriteria responden yang dibutuhkan untuk mampu menjawab kuesioner adalah calon mahasiswa di Jakarta atau siswa siswi SMA di Jakarta, aktif menggunakan jejaring sosial dan pernah membaca ulasan secara online tentang suatu Universitas. Jumlah sampel dalam penelitian ini sebesar 200 calon mahasiswa yang memenuhi kriteria tersebut.

Pengukuran Variabel

Terdapat empat variabel yang digunakan dalam penelitian ini yaitu perceived e-WOM, corporate image, customer involvement dan purchase intention. Keempat variabel tersebut diukur dengan memanfaatkan instrumen yang pernah digunakan oleh Bataineh (2014) dan Lin et al. (2013). Skala pengukuran yang digunakan adalah skala likert 1 (sangat tidak setuju) sampai dengan 5 (sangat setuju).

Menurut Hair et al. (2010), dengan jumlah sampel 200 maka loading factor indikator untuk dinyatakan valid adalah 0,4 keatas. Hasil uji validitas menunjukkan semua indikator variabel e-WOM, corporate image, customer involvement dan purchase intention nilainya diatas 0,4 yang artinya semua indikator dapat mengukur variabel-variabel tersebut.

Demikian juga hasil uji reliabilitas menunjukkan bahwa instrumen reliabel, karena semua variabel memiliki nilai cronbach alpha diatas 0,6 . Hal ini berarti terdapat konsistensi internal antar indikator yang digunakan untuk mengukur setiap variabel dalam penelitian ini.

Metode Analisis Data

Metode analisis data penelitian ini menggunakan analisa SEM. SEM (Structural Equation Modeling) adalah suatu teknik statistik multivariate yang mengkombinasikan aspek regresi berganda dan analisis faktor untuk mengestimasi serangkaian hubungan ketergantungan secara simultan (Hair et al., 2010). Metode SEM tepat digunakan sesuai dengan model penelitian yang dibahas dalam tinjauan pustaka sebelumnya. Dalam model tersebut terdapat variabel intervening atau mediating dan variabel moderating.

Sebelum dilakukan uji hipotesis, maka dilakukan uji kesesuaian model (Goodness of Fit/ GOF). Hasil uji GOF menunjukkan bahwa model penelitian cukup fit dengan data yang diperoleh. Hal ini dapat dilihat dari tabel uji GOF berikut ini : 
Tabel 1

Pengujian Model

\begin{tabular}{cccc}
\hline Pengukuran & Nilai & Batas GOF & Kesimpulan \\
\hline Chi Square & P value $=0,000$ & P value $>0,05$ & Tidak GOF \\
GFI & 0,809 & $>0,9$ & Marginal GOF \\
RMSEA & 0,070 & $<0,08$ & GOF \\
RMR & 0,066 & Kecil, mendekati 0 & GOF \\
PNFI & 0,528 & Antara 0 sampai 1 & GOF \\
PCFI & 0,659 & Antara 0 sampai 1 & GOF \\
\hline
\end{tabular}

Dari tabel hasil uji GOF tersebut nampak bahwa nilai RMR kecil mendekati 0; nilai PCFI dan PNFI berada diantara range value yaitu antara 0 sampai 1; sedangkan nilai RMSEA kurang dari 0,08 . Nilai-nilai tersebut memenuhi syarat kelayakan sebuah model, sehingga uji hipotesis bisa dilakukan.

\section{Pembahasan dan Kesimpulan}

Pembahasan

Hasil pengujian hipotesis satu, dua dan tiga dapat dilihat dari tabel dibawah ini :

Tabel 2

Hasil Pengujian Hipotesis 1, 2 dan 3

\begin{tabular}{cccc}
\hline Hipotesis & Estimasi & p-value & Kesimpulan \\
\hline $\begin{array}{l}\text { H1 : Terdapat pengaruh e-WOM } \\
\quad \text { terhadap purchase intention }\end{array}$ & 0,329 & 0,067 & Tidak didukung \\
$\mathrm{H} 2$ : Terdapat pengaruh e-WOM & 0,780 & 0,000 & Didukung \\
$\quad$ terhadap corporate image & & 0,014 & Didukung \\
$\mathrm{H} 3$ : Terdapat pengaruh corporate & 0,462 & & \\
$\quad \begin{array}{l}\text { image terhadap purchase } \\
\text { intention }\end{array}$ & & & \\
\hline
\end{tabular}

Dari tabel tersebut dapat dilihat bahwa tidak terdapat pengaruh e-WOM terhadap purchase intention (dapat dilihat dari nilai $p$ value yang lebih dari 0,05 ). Hal ini berarti semakin tinggi kredibilitas, kualitas dan kuantitas e-WOM maka tidak menjamin calon mahasiswa akan semakin berniat untuk mendaftarkan diri ke universitas yang diulas secara on line. Hasil penelitian ini tidak mendukung hasil penelitian yang dilakukan oleh Park et al. (2007). Untuk sampai pada niat mendaftar pada sebuah universitas, calon mahasiswa harus mempunyai persepsi image yang baik terlebih dahulu terhadap universitas tersebut atau calon mahahiswa harus merasa bahwa pendidikan tinggi adalah sangat penting dan 
bernilai dalam kehidupan mereka (Bataineh, 2015 dan Lin et al., 2013). Dugaan ini akan diuji dalam hipotesis empat dan lima.

Untuk hipotesis berikutnya yang menyatakan terdapat pengaruh e-WOM terhadap corporate image didukung dengan nilai $p$ value 0,000 dan nilai estimasi positif 0,780. Semakin calon mahasiswa merasa bahwa kredibilitas dan kualitas e-WOM adalah baik diikuti jumlah e-WOM yang mencukupi maka image universitas tersebut semakin dianggap baik. Hasil penelitian ini mendukung hasil penelitian yang dilakukan oleh Bataineh, 2015.

Dari tabel tersebut dapat dilihat bahwa terdapat pengaruh corporate image terhadap purchase intention. Hal ini dapat dilihat dari nilai $p$ value yang kurang dari 0,05 ( $p$ value= 0,014 ). Bentuk pengaruh adalah positif (karena nilai estimasi bertanda positif 0,462 ) yang berarti semakin tinggi image suatu universitas maka calon mahasiswa akan semakin berniat untuk mendaftarkan diri ke universitas yang diulas secara on line. Hasil penelitian ini mendukung hasil penelitian yang dilakukan oleh Bataineh, 2015.

Untuk menguji hipotesis empat, yaitu peran variabel corporate image dalam memediasi hibungan e-WOM dengan purchase intention, maka model akan di bagi dua untuk dibandingkan. Model pertama adalah model yang hanya menunjukkan pengaruh langsung e-WOM terhadap purchase intention. Sedangkan model kedua, sudah memasukkan variabel corporate image yang memediasi pengaruh e-WOM dengan purchase intention.

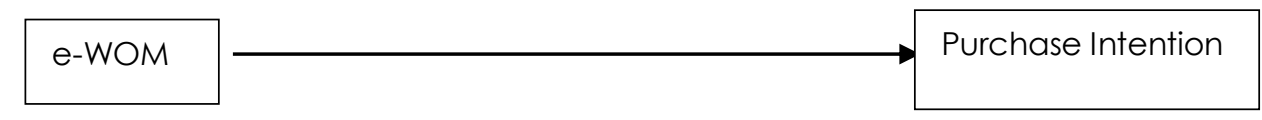

Gambar 2

Model 1 : Pengaruh langsung e-WOM terhadap purchase intention

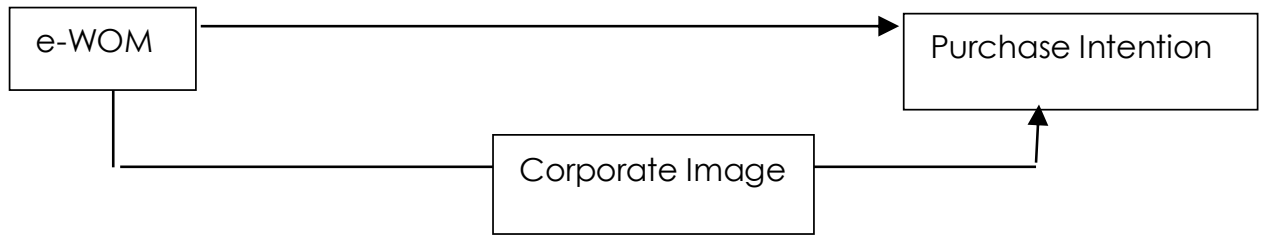

Gambar 3

Model 2 : Peran corporate image dalam memediasi pengaruh e-WOM terhadap purchase intention 
Menurut Baron and Kenny (1986), variabel corporate image berperan menjadi variabel mediasi jika memenuhi beberapa syarat. Syarat tersebut adalah : (a) harus ada pengaruh yang signifikan antara e-WOM terhadap corporate image, (b) harus ada pengaruh yang signifikan corporate image terhadap purchase intention, (c) jika pengaruh langsung e-WOM terhadap purchase intention model satu signifikan, dibanding model dua menjadi tidak signifikan atau tetap signifikan tetapi nilai signifikansinya menjadi menurun. Hasil pengujian hipotesis empat dapat dilihat pada tabel berikut ini :

Tabel 3

Hasil Pengujian Hipotesis 4

\begin{tabular}{cccc}
\hline Model & Estimate & p-value & Kesimpulan \\
\hline $\begin{array}{c}\text { Model 1 } \\
\begin{array}{c}\text { Terdapat pengaruh e-WOM } \\
\text { terhadap purchase intention } \\
\text { Model 2 }\end{array}\end{array}$ & 0,611 & 0,000 & $\begin{array}{c}\text { Ada pengaruh } \\
\text { positif }\end{array}$ \\
$\begin{array}{c}\text { Terdapat pengaruh e-WOM } \\
\text { terhadap corporate image }\end{array}$ & 0,780 & 0,000 & $\begin{array}{l}\text { Syarat a } \\
\text { terpenuhi (Sig.) } \\
\text { Terdapat pengaruh corporate } \\
\text { image terhadap purchase } \\
\text { intention }\end{array}$ \\
$\begin{array}{c}\text { Terdapat pengaruh e-WOM } \\
\text { terhadap purchase intention }\end{array}$ & 0,462 & 0,014 & $\begin{array}{l}\text { Syarat b } \\
\text { terpenuhi (Sig.) }\end{array}$ \\
& 0,329 & 0,067 & $\begin{array}{l}\text { Syarat c } \\
\text { terpenuhi } \\
\text { (menjadi tidak } \\
\text { signifikan) }\end{array}$ \\
\hline
\end{tabular}

Dari tabel tersebut dapat dilihat bahwa pada model satu terdapat pengaruh e-WOM terhadap purchase intention ( $p$ value $=0,000$ ) dan menjadi tidak signifikan pada model dua ( $p$ value $=0,067$; memenuhi syarat $c$ ), dan syarat terdapat pengaruh e-WOM terhadap corporate image ( $p$ value=000; syarat $a$ ) maupun syarat terdapat pengaruh corporate image terhadap purchase intention ( $p$ value $=0,014$; syarat $b$ ) juga terpenuhi pada model dua. Dengan demikian hipotesis empat yang menyatakan bahwa e-WOM mempengaruhi purchase intention melalui corporate image didukung. Hasil penelitian ini sesuai dengan hasil penelitian yang dilakukan oleh Bataineh, 2015. Dengan hasil pengujian ini bisa juga menjelaskan alasan mengapa hipotesis satu yang menyatakan adanya pengaruh langsung e-WOM terhadap purchase intention (dalam model penelitian) tidak didukung, namun demikian dengan e-WOM yang dapat menimbulkan corporate image yang baik maka 
akan dapat meningkatkan purchase intention. Dengan kata lain pengaruh e-WOM terhadap purchase intention adalah pengaruh tidak langsung. Dapat disimpulkan bahwa hanya e-WOM yang dapat menimbulkan image universitas menjadi baik yang dapat meningkatkan minat calon mahasiswa untuk mendaftar pada universitas tersebut.

Untuk menguji hipotesis lima, yaitu peran variabel customer involvement dalam memoderasi hibungan e-WOM dengan purchase intention, maka model akan di bagi dua untuk dibandingkan. Model pertama adalah model yang menunjukkan pengaruh e-WOM terhadap purchase intention untuk kelompok responden yang memiliki keterlibatan tinggi. Sedangkan model kedua, adalah model yang menunjukkan pengaruh e-WOM terhadap purchase intention untuk kelompok responden yang memiliki keterlibatan rendah. Hasil pengujian hipotesis lima dapat dilihat pada output bagian notes for model maupun model fit summary unconstrained yang menunjukkan angka probability level 0,000. Hal ini menunjukkan bahwa ada perbedaan antaradua kelompok calon mahasiswa (kelompok yang mempunyai keterlibatan tinggi dan kelompok yang mempunyai keterlibatan rendah berkaitan dengan penting tidaknya pendidikan tinggi) dalam niat perilaku mereka untuk mendaftar pada sebuah universitas berdasarkan stimulus e-WOM yang sama. Secara lebih terperinci perbedaan model perilaku antara calon mahasiswa yang mempunyai keterlibatan tinggi dan rendah berkaitan dengan penting tidaknya pendidikan tinggi dapat dilihat sebagai berikut :

Tabel 4

Hasil Pengujian Hipotesis 5

\begin{tabular}{lccc}
\hline \multicolumn{1}{c}{ Model } & Estimasi & p-value & Kesimpulan \\
\hline \multicolumn{1}{c}{ Model 1 } & 0,606 & 0,000 & Ada pengaruh \\
$\begin{array}{l}\text { Terdapat pengaruh e-WOM } \\
\text { terhadap purchase intention (high } \\
\text { involvement) } \\
\quad \text { Model 2 }\end{array}$ & & & positif \\
$\begin{array}{l}\text { Terdapat pengaruh e-WOM } \\
\text { terhadap purchase intention (low } \\
\text { involvement) }\end{array}$ & 0,289 & 0,132 & Tidak ada \\
\hline
\end{tabular}

Dari tabel tersebut dapat dilihat bahwa pengaruh e-WOM terhadap purchase intention hanya signifikan untuk kelompok responden yang memiliki high involvement. Ini membuktikan bahwa customer involvement dapat memoderasi pengaruh e-WOM terhadap purchase intention. Hasil pengujian hipotesis lima ini juga dapat memberikan alasan mengapa hipotesis penelitian yang menyatakan adanya pengaruh langsung eWOM terhadap purchase intention dalam model penelitian ini tidak didukung. Pengaruh 


\section{Fatik Rahayu}

ulasan on line tentang sebuah universitas terhadap minat mendaftarkan pada universitas tersebut hanya berlaku bagi calon mahasiswa yang menganggap pendidikan tinggi penting dan berharga. Dengan kata lain, ada peran customer involvement dalam hubungan e-WOM dan purchase intention. Hasil penelitian ini sesuai dengan hasil penelitian yang dilakukan oleh Lin et al. (2013).

\section{Kesimpulan}

Hasil penelitian menunjukkan bahwa tidak terdapat pengaruh e-WOM terhadap purchase intention, terdapat pengaruh e-WOM terhadap corporate image, terdapat pengaruh corporate image terhadap purchase intention,e-WOM mempengaruhi purchase intention melalui corporate image dan pengaruh e-WOM terhadap purchase intention dimoderasi oleh customer involvement. Dengan kata lain, variabel corporate image merupakan variabel mediasi dalam hubungan antara e-WOM dengan purchase intention. Hal ini berarti bahwa dengan e-WOM yang baik diharapkan akan menimbulkan corporate image yang baik juga, yang pada gilirannya dengan corporate image ini e-WOM akan mempunyai pengaruh pada purchase intention. Variabel customer involvement merupakan variabel moderasi dalam hubungan antara e-WOM dengan purchase intention. Hal ini berarti pengaruh corporate image terhadap purchase intention hanya efektif jika keterlibatan konsumen cukup tinggi dalam proses pembelian. Dalam penelitian ini, keterlibatan konsumen berkaitan dengan persepsi konsumen terhadap penting tidaknya sebuah jasa pendidikan tinggi.

\section{Implikasi dan Keterbatasan}

Untuk meningkatkan minat mendaftar calon mahasiswa, maka pengelola sebuah universitas harus dapat menjamin adanya image yang baik dari universitas tersebut dan mensosialisasikan arti penting dari suatu pendidikan tinggi bagi kehidupan. Untuk mencapai dua hal tersebut maka pengelolaan e-WOM merupakan salah satu strategi yang bisa dilakukan oleh pihak universitas. Berdasar hasil penelitian ini, beberapa cara mengelola eWOM adalah sebagai berikut :

1. Menjaga kredibilitas e-WOM dengan cara melibatkan beberapa pakar pendidikan dan para alumni yang sudah sukses untuk memberikan ulasan tentang universitas secara on line. Sumber penyampai pesan sangat mempengaruhi efektifitas dari sebuah pesan (Kotler and Keller, 2012). Beberapa hal yang dianggap mempengaruhi tinggi redahnya kredibilitas sumber penyampai pesan adalah berkaitan dengan kepakaran, tingkat likeability dan trustworthiness seseorang. Pakar pendidikan merupakan orang yang dianggap memiliki keahlian dibidang 


\section{Jurnal Manajemen Teori dan Terapan \\ Tahun 10. No. 1, April 2017}

pendidikan dan alumni merupakan orang yang dianggap memiliki tingkat trustworthiness yang tinggi tentang kualitas sebuah universitas.

2. Menjaga kualitas e-WOM dengan cara memberikan isi dan format ulasan agar jelas dan berdasarkan alasan yang kuat. Isi sebuah pesan harus menarik perhatian. Menurut Kotler dan Keller (2012), daya tarik sebuah pesan bisa bersifat rasional atau emosional. Daya tarik rasional merupakan daya tarik yang dianggap tepat untuk jasa pendidikan tinggi yaitu alasan yang masuk akal bagi calon mahasiswa. Alasan yang masuk akal ditunjukkan dengan kualitas pendidikan yang tinggi.

3. Meningkatkan jumlah e-WOM dengan cara terus menerus memperbaiki kualitas layanan pendidikan sesuai tuntutan stakeholders. Frekuensi merupakan salah satu hal yang ikut mempengaruhi efektifitas sebuah pesan (Kotler and Keller, 2012). Makin tinggi fekuensi atau jumlah pesan disampaikan maka diharapkan makin diperhatikan oleh calon mahasiswa, apalagi dengan dukungan kualitas pelayanan yang baik.

Selain itu, persepsi calon mahasiswa tentang pentingnya sebuah pendidikan tinggi juga perlu ditingkatkan. Bagaimana dampak sebuah proses pendidikan tinggi bagi kehidupan pribadi maupun kehidupan berbangsa harus diberikan pada para calon mahasiswa melalui berbagai program promosi.

Penelitian ini masih menggunakan prosedur penarikan sampel secara non probability sampling, sehingga kesimpulan kurang bisa di generalisasi. Penelitian ini hanya fokus pada variable e-WOM saja dalam mempengaruhi purchase intention baik secara langsung maupun melalui corporate image dan peran mediasi customer involvement sebagai variabel moderating dalam hubungan e-WOM dengan purchase intention. Masih banyak variabel lain yang perlu dipertimbangkan untuk diteliti lebih lanjut agar model penelitian bisa lebih mewakili fenomena yang sebenarnya.

Penelitian selanjutnya diharapkan dapat mengatasi keterbatasan masalah seperti diuraikan sebelumnya. Variabel lain seperti attitude, perceived behavioral control, subjective norm, servicequality, perceived value, Marketing mix efforts (Jalilvand and Samiei, 2012; Kim and Hyun, 2011; Hu et al., 2009) dapat dipertimbangkan dalam penelitian selanjutnya agar model penelitian menjadi lebih baik.

\section{DAFTAR REFERENSI}

Andreassen, T. W. And Lanseng, E. 1998. Customer Loyalty and complex services: The impact of corporate image on quality, customer satisfaction and loyalty for customers with varying degreesof service expertise. International Journal of Service Industry 
Management, 9/1, pp. 7-23.

Assael, H. 2001. Consumer Behavior and Marketing Action. $7^{\text {th }}$ Edition, New York University.

Baron, R.M. and Kenny, D.A. 1986. The moderator-mediator variable distinction in social psychological research: Conceptual, strategic, and statistical considerations. Journal of Personality and Social Psychology, 51/6: 1173-1182.

Bataineh, A. Q. 2015. The Impact of Perceived e-WOM on Purchase Intention : The Mediating Role of Corporate Image. International Journal of Marketing Studies, 7/1 : 126-136.

Bhattacherjee, A. A. S. 2006. Influence process for information technology acceptance: an elaboration likelihood model. MIS Quarterly, 30/4 : 805-825.

Boyd, B. K., Bergh, D. D., \& Ketchen Jr., D. J. 2010. Reconsidering the reputation-performance relationship:A resource-based view. Journal of Management, 36/3 : 588-609.

Bian, X. and Moutinho, L. 2011.The Role of Brand Image, Product Involvement, and Knowledge In Explaining Consumer Purchase Behaviour of Counterfeits: Direct and Indirect Effect.European Journal of Marketing, 45 / 2 :191.

Chattereje, P. 2001. Online Review: Do Consumer Use Them?, Advance in Consumer Research, 28/1:129-33.

Cheung, C. M.K and Lee, M.K.L. 2012. What drives consumers to spread electronic word of mouth in online consumer opinion platform. Decision Support System, 53 : 218-225.

Cheung, C. M. K.\& Thadani, D. R. 2010. The Effectiveness of Positive Electronic Word-of-Mouth Communication: A Literatur Analysis.23rd Bled eConference eTrust; Bled Slovenia.

Chevalier, J.A. \& Mayzlin D. 2006.The Effect of Word of Mouth On Sales: Online Book Revie.Journal of Marketing Research, $43: 345-54$.

Di, C. and Wang, L. 2012. Factor Affecting e-WOM Adoption. BBA Honours, Hong Kong Baptist University.

Fatima, J. K. And Razzaque, M. A. 2014. Roles of Trust on Rapport and Satisfaction in Service. Asia Pasific of Journal Marketing and Logistics, 26/24:566-578.

Fogg, B. J., Kameda, T., Boyd, J., Marshall, J., Sethi, R., Sockol, M., \&Trowbridge, T. 2002. Stanford Makovsky Web Credibility Study 2002: Investigating What Makes Web Sites Credible Today. A Research Report by the Stanford Persuasive Technology Lab \& Makovsky \& Company, Stanford University.Retrieved from www.webcredibility.org

Hair, J., Anderson, R., Tatham, R., \& Black. 2010. Multivariate Data Analysis . $7^{\text {th }}$ Edition. Upper Saddle River, NJ : Prentice Hall.

Harrison-Walker, L. J. 2001. The Measurement of Word-of-Mouth Communication and an Investigation of Service Quality and Customer Commitment as Potential Antecedents. Journal of Service Research, $4: 60-75$.

Hennig-Thurau, T., Gwinner, K.P., Walsh, G. dan Gremler, D.D. 2004. Electronic Word-of-Mouth via Consumer-Opinion Platforms: What Motivates Consumers to Articulate Themselves On the Internet? .Journal of Interactive Marketing, 18/1 : 38- 52.

Hsu, C. L. And Chen, J. C. L. 2008. Acceptence of blog usage : the role of technology acceptane, social influence and knowledge sharing motivation. Information and Mangement, 45/1:65-74.

Hu, H. H. S.; Kandampull, J.y \& Juwaheer, T. 2007. Relationships and impacts of service quality, perceived value, customer satisfaction, and image: an empirical study. The Services Industries Journal, 29/2:111-125.

Jalilvand, M. R. dan Samiei, N. 2012. The Effect of Electronic Word of Mouth On Brand Image and Purchase Intention: An Empirical Study in the Automobile Industry in Ira., Marketing Intelligence \& Planning, 30/4 : $460-476$.

Jalilvand, M. R. dan Samiei, N. 2012.The Impact of Electronic Word of Mouth On A Tourism 
Destination Choice: Testing the Theory of Planned Behavior (TPB).Internet Research, Vol. 22 Iss: $5: 591-612$.

Jefkins, F. 2004. Public Relation. 5th edition. New York: Willey.

Kim, J. H. And Hyun, Y. J. 2011. A Model to Investigate the Influence of Marketing Mix Effort and Corporate Image on Brand Equity in the IT Software Sector. Industrial Marketing Management, $40: 424-438$.

Kotler, P.and Keller, K. L. 2012. Marketing Management 13th Edition. New Jersey : Prentice Hall.

Lin, C., Wu, Y., \& Chen, J. 2013. Electronic Word-Of-Mouth: The Moderating Roles Of Product Involvement And Brand Image. Proceedings of 2013 international conference on technology innovation and industrial management, Phuket, Thailand.

Lee, J.; Park, D. H. And Han, I. 2008. The Effect of On Line Consumers Reviews on Consumers Purchasing Intention: The Moderating Role of Involvement. International Journal of Electronic Commerce, 11/4: 125-148.

Mowen, J. And Minor, M. 2002. Consumer Behavior. 5th edition. New Jersey : Prentice Hall.

Norman, P. and Smith, L. 1995. The theory of planned behavior and exercise : An investigation into the role of prior behavior, behavior intention and attitude variability. European Journal of Social Psychology, 25/4 : 403-415.

Peter, P. J. And Olson, J. C. 2008. Consumer Behavior and Marketing Strategy, Mc Graw Hill.

Ruben, B. D. Stewart, L. P. 1998. Communication and Human Behavior, USA Viacom Company.

Sher, P. J. And Lee, S. H. 2009. Customer Skepticism and online review : An elaboration likelihood model perspective. Social Behavior and Personality, 37/1 : 137-144.

Zeithaml, V.A., Bitner, M.J., \& Gremler, D.D. 2012. Services Marketing: Integrating Customer Focus Across the Firm. $4^{\text {th }}$ Edition. Singapore: McGraw-Hill. 